\title{
MILITARY INVOLVEMENT IN LATIN AMERICAN POLITICS
}

\author{
Dirk Kruijt, ${ }^{1}$ \\ Utrecht University, Instituto Universitário Lisboa
}

\begin{abstract}
During the last two centuries, the military in Latin America has been involved in politics in a characteristic duality of professionalism and political 'calling', by political armies of the right and the left. In both cases, a kind of 'military mystique' prevails, but its content is different. In both cases, the military justifies its involvement as a consequence of its necessary correcting and transforming vanguard role in politics and society. The two characteristics of dual functions (internal and internal security) and dual pathways (professionalism and political missions) are a revolving theme in this article.
\end{abstract}

\section{Introduction: Political armies}

Latin America is a continent of political soldiers and military politicians. The military profession is often a prelude to a political career. During two centuries of independent republics, the militaries have been important, decisive and intermittently ruling political actors. In the nineteenth century, caudillos (military officers with an armed entourage) took power as military rulers, but from the early twentieth century onward, not individual strongmen but the military institution itself became a key power broker in almost every country. In this article, I follow the evolution and transformation of the Latin American military in politics and society.

During the entire twentieth century, very few inter-state wars were fought in Latin America. At best, one real war, the Chaco War between Bolivia and Paraguay, was waged in the 1930s. Maybe one should add the rather reduced campaigns of the El Salvador-Honduras conflict in the 1960s and the Falklands conflict in the early 1980s where a British expeditionary force defeated an Argentine army detachment. Most wars were prolonged, but loose sequences of relatively insignificant military skirmishes, whatever their number of casualties. Inter-state conflicts were in fact localised micro-wars, generally extended frontier disputes. Latin American countries do not have external territorial enemies in the sense of aggressive competitive states. Nobody thinks seriously of modern, large-scale warfare scenarios between, for instance, Brazil and Guyana, Argentine and Uruguay, Mexico and Guatemala.

This means that militarism in a conventional sense - meaning the predominance of the military institution and its key ideological constructs in shaping national life because of real or perceived external security threats ${ }^{2}-$ is much less visible throughout modern Latin American history. In fact, the soldiering of the Latin American military 
has been confined largely by its acting in internal social and political conflict. There is a long tradition of military involvement in persecuting and combating internal enemies, by internal warfare and counterinsurgency campaigns. In that sense, the Latin American military has demonstrated its proclivity to act as the guardian of the nation, as protector of the state against all its threats and all its enemies, sometimes opposing external ones, but generally combating enemies within.

As a stabilising force, as disinterested arbiter, as a protecting power of the constitution and as guardian of national development, the military intervened in political matters, thus becoming 'political armies'3 After the 1980s, democratic transitions have diminished the influence of the higher echelons in the military. In part, this has meant a move towards conventional, apolitical professionalism as the Latin American military sought new roles in a redefined national, regional and global security environment, However, a much more prominent trend has been the militarisation of law enforcement in a context of what Arias and Goldstein typified as 'violent democracies', a scenario where a variety of non-state actors were engaged in armed disputes in smaller or larger territories. ${ }^{4}$

In this historiographic article, I report on the origins and evolution of the Latin American military in politics.

- What were and are the main characteristics of military political involvement?

- How does one explain the explosion of military dictatorship in eleven Latin American countries?

- What was the power base of the military muscle?

- What about the dual military role of persecuting internal enemies and confronting external threats?

- What was the role of para-military deployments?

- Who are the ideologues?

- What is the role of the so-called 'military intellectuals'?

- What is the legacy of the military dictatorship and/or military co-government of the right and the left?

- How does one explain the persistent preference for military presidents in uniform or after retirement?

- How should one interpret the manifold new missions in peacetime and democracy?

- Is there a risk of recurrent political involvement of the military echelons, this time as executive instrumentalisation after a presidential self-coup or an eroding democracy? 
I will also refer to the changing context of democracy facing insecurity at the end of the twentieth century until the present. What are the new security challenges being faced and how do they influence the orientation and role of their military institutions? I will argue that some of the new present security problems once again draw the military into domestic tasks and roles. To what extent is this only a consequence of security policies of democratically elected civilian governments? Or does it still mean the actual existence, or the potential threat, of political militarism, even by civilian invitation?

\section{Characteristics}

In the colonial Portuguese captaincies in general, as well in the Spanish vicekingdoms, the first military organisations were militias formed by landlords and their subordinated tenants. The Iberian kingdoms also sent small military and naval contingents. Iberian military and local militias were engaged in three complementary tasks: fighting and controlling the native indigenous population, defence against European buccaneers, and frontier skirmishes between rivalling Spanish and the Portuguese colonisers. The principal military deployment was campaigning against 'wild' and rebellious indigenous warriors who assaulted colonial villages or tried to re-establish indigenous empires. Loveman who reviewed the nineteenth-century constitutions and organic laws in Spanish America and Brazil, concludes that these provided the armed forces with a legal role expansion far beyond conventional defence tasks. ${ }^{5}$ Analysing the regimes of exception in nineteenth-century Latin America, he uses the term "constitutional tyrannies".

Political armies emerged during the last decades of the nineteenth century and reappeared between the 1930s and the 1950s. Especially during the Cold War, military juntas (commanders of the army, navy and air force) were time and again collective heads of state and governments in most countries in the region. The Latin American military corporate ethos, in their own terms, the military mystique, which implied a certain calling and moral responsibilities (mística militar in Spanish and Portuguese), had legitimising notions. Civilian politicians will emphasise that military men and women are sons and daughters of the nation. Military ideologues will underline the relationship of unity, even kinship, between the military and the national population. However, they are especially inclined to formulate these bonds in terms of fathers of the Patria, implying the need to protect the nation and its basic interests, which in its turn justified the necessity of intervention in times of crisis. It also means a sometimes benevolent and sometimes punitive stance with respect to the civilian population in terms of fathers versus children, adults versus adolescents, strong leadership versus weak followers. ${ }^{6}$

One can discern persistent beliefs. ${ }^{7}$ Firstly, the military as institution claims a certain 'birthright' (sometimes real; at other times supposed), which enables it to perceive the national interests and destiny unmistakably and to define the strategies for national development. ${ }^{8}$ Then there is the idea of non-political competence in matters of planning, technology and efficiency, in which militaries are specially trained to acquire proficiency. Thirdly, there is the conviction that officers are selected because of their 
aptness for unselfish sacrifice ('we give our life') and special military virtues such as discipline, valour, rectitude, self-denial and patriotism. Fourthly, militaries represent par excellence the vigorous unity of the nation, and they have the willpower to achieve and sustain it notwithstanding hardship and danger. Lastly, the militaries are inclined to believe that civilian politicians represent at best class interests instead of global national welfare. Thus, civilians are divided, self-interested and maybe corrupt, and in any case inadequate, in times of crisis. Military leadership as the ultimate protectors of the nations is oriented to stability and resolve.

\section{Institutional coups}

The paradoxical duality of military professionalism and political 'calling' has been an ongoing theme over the last 75 years. I will make a distinction between political armies of the right and the left. In both cases, a kind of military mystique prevails, but its content is different. Political armies of the right are in general heavy-handed, repressive regimes (dictatorships or civil-military governments) supporting elite and middle-class interests and repressing 'enemies of the nation'. But political armies can also gyrate to the left (pro-poor military governments with popular support) while implementing reformist political projects intended to favour the poor, underprivileged and excluded. The military institutions of eleven Latin American countries established long-term military-led governments between 1964 and 1990:

- Ecuador (1963-1966, 1972-1978),

- Guatemala (1963-1985),

- Brazil (1964-1985),

- Bolivia (1964-1970, 1971-1982),

- Argentina (1966-1973, 1976-1983),

- Peru (1968-1980),

- Panama (1968-1989),

- Honduras (1963-1966, 1972-1982),

- Chile (1973-1990),

- (Uruguay, 1973-1984), and

- in El Salvador, the military governed de facto between 1948 and $1984 .{ }^{9}$

When the long period of military governments came to its end in the late 1980, the military concern for the fate of the nations only diminished and became more latent, but it never disappeared. 


\section{Security doctrines and military intellectuals}

Latin American geopolitical scholarship was shaped in the late nineteenth and the early twentieth century, when most regional governments invited European military missions to train the officers' corps and to create armies by force of selective conscription. ${ }^{10}$ Their influence lasted until the Second World War. After 1945, US military assistance imported its own brand of geopolitical preferences.

The Cold War reinforced the US hegemony in military- and security-related assistance to Latin America. This development aid was originally mostly military, gradually combined with support from the new American intelligence community (especially the Central Intelligence Agency [CIA], afterwards also the Drug Enforcement Administration [DEA]). Under the US umbrella thesis of 'continental security', the complementary domestic thesis of 'national security' merged with the geopolitical Latin American military tradition. The authors of these theses were a new brand of Latin American officers, 'military intellectuals' of the staff schools and training institutes.

In countries such as Brazil, Chile and Peru, these intellectuals provided coherent ideologies in which the formal role of the armed forces was expanded: from defence against territorial attacks and foreign enemies to an active contribution to national development with the identification of problems and threats, solutions for overcoming development obstacles, civil-military planning and solutions. Future Chilean President, General Pinochet, published his geopolitical lectures in the 1960s and 1970s, as did future Peruvian Prime Minister and Minister of Defence General Mercado Jarrín. His future colleague as Minister of Defence in Guatemala, General Gramajo, followed his example in the 1980s. In fact, the functions of geopolitical scholar, intelligence director, military strategist, military intellectual and military president or prime minister were an integral part of the career moves of leading military in Brazil (Golbery do Couto e Silva ${ }^{11}$ ), Chile (Pinochet ${ }^{12}$ ), Peru (Mercado Jarrín $^{13}$ ) and Guatemala (Gramajo $\left.{ }^{14}\right)$.

Three of the Latin American countries deeply affected by their military governments in Brazil, Guatemala and Peru, created influential study centres, where military intellectuals lectured, wrote, thought and prospered. These academies were established both for military officers (colonels and brigadiers) and for civil servants (senior technocrats, entrepreneurs, academics, labour leaders and journalists). The Brazilian and Peruvian higher civil military schools, the Escola Superior de Guerra (ESG), and the Centro de Altos Estudios Militares (CAEM) were created in the late 1940s and early 1950s, long before the military coups of 1964 (Brazil) and 1968 (Peru). Their ideological influence on the mystique of the subsequent military governments is undeniable. $^{15}$

The ESG was created in 1949, and was modelled after the US War College. ${ }^{16}$ From its inception, the ESG highlighted the need for a strong army presence in planning, economic development, industry and agriculture to overcome underdevelopment 
in Brazil. Fostering a civilian elite of competent planners and technocrats at the ministries and supporting national and regional entrepreneurship was also considered a core necessity. Their acknowledgement of and conformity with the ideas of Brazilian national security were considered essential. Golbery, the chief theoretician, emphasised national unity and productive capacity of the entire nation as vital. In the 1960s, the emphasis on counterinsurgency and irregular counter-guerrilla warfare (more than strictly territorial defence) gradually increased, eventually to reach 222 versus 21 hours of study in 1968. Eminent military and civilian professors, even ministers in function, augmented the prestige of the ESG.

The CAEM was created in 1950. Its founder, General Marín, a nationalist rather than an anti-communist or pro-American, turned on the UN regional office ECLAC (United Nations Economic Commission for Latin America and the Caribbean) in Santiago de Chile where Prebisch and his colleagues had launched concepts like 'underdevelopment' and 'centre-periphery'. By the end of the 1950s and the early 1960s, the alumni wrote theses dealing with topics such as development planning for the Amazon region, and Andean agriculture. In the 1960s, the CAEM staff lectured on 'integral development' and the leading progressive scholars, on history, anthropology, philosophy and political ideas. In fact, nearly all the colonels who prepared the Velasco coup of 1968 were members of Velasco's advisory group, were previously intelligence officers, and then put in charge of the counterinsurgency operations against the guerrilla movements in the mid-1960s. They secretly convened in study groups where they discussed the ideas of Peruvian Marxist historian and anthropologist Mariátegui, and decided that not the guerrilla members, but the landed elite were the real enemies within. They further argued that they needed a series of structural reforms as the only remedy against poverty, exclusion and imperialism, the real causes of the insurgency.

In Guatemala, the Centro de Estudios Estratégicos Nacionales (Centro ESTNA) was founded in 1988, as a think-tank of the Fundación para el Desarrollo Institucional de Guatemala (DIG). Contrary to its predecessors in Brazil and Peru, it was established as a post-civil war civil-military graduate school. It functioned during the period of military tutelage until the late $1990 \mathrm{~s} .{ }^{17}$

\section{Military of the right}

In many countries of the region, the Cold War was a period of persecution, repression and civil war. Military coups became institutionalised. ${ }^{18}$ The first institutional coup took place in Peru in 1962. But the most important one was the military takeover in Brazil, in 1964. ${ }^{19}$ This latter coup was planned after explicit consultation with the national elite and with US government representatives. ${ }^{20}$ The Brazilian example gave rise to a sequence of Latin American dictatorships, afterwards known as 'national security regimes', of right-wing military army leaders where a succession of military cabinet members in military or civil-military governments was arranged by internal promotions within the army, the navy and the air force. ${ }^{21}$ 
Many of these regimes were at war with their own society, persecuting 'enemies within' and in some cases, explicitly engaged in internal warfare. Their ideology was one of fervent anti-communism, the product of 'exotic theories', according to Argentinean army chiefs. They fought counterinsurgency wars against 'subversive' or 'terrorist' adversaries, real (members of guerrilla movements) or imagined (the leadership of trade unions and peasant associations, left-wing writers and students, journalists and priests). In the case of Argentina, Brazil, Chile and Uruguay, and especially Central America, the counterinsurgency campaigns took the form of dirty warfare: state terrorism, including widespread torture, assassinations and disappearances, even amounting to genocide (in the case of Guatemala). ${ }^{22}$ In Brazil and the Southern Cone countries, repression was carried out not only to deal with known adversaries, but also to instil fear within society. Open civil war in Central America followed the same basic pattern of conflict leading to an even much larger number of victims.

The military muscle of the dictatorships was based on three components: control over the national system of intelligence and security forces, the predominance of the military over the police forces, and the already mentioned military missions of local and regional development in remote areas. Of these three factors, control over security and intelligence was the most important. The internal wars against subversion were conducted by an array of parallel services: military intelligence, the security organs, the police, para-military groups and death squads and combinations thereof. As the backbone of the counterinsurgency operations, the intelligence and security systems expanded to such a degree that their official and unofficial ties with paramilitary units became difficult to distinguish. ${ }^{23}$

The use of paramilitary forces as auxiliary deterrent and local enforcement could take grotesque forms. Semi-governmental vigilantes, such as the AAA (Argentine Anti-Communist Alliance or Triple A) in Argentina, two parallel paramilitary forces in El Salvador, and particularly the Self-Defence Patrols (PACs) in Guatemala, terrorised their countries. At the height of the counterinsurgency campaigns in Guatemala, the army forcefully incorporated more than a million indigenous 'civil patrol members', probably half of the entire indigenous adult male population, out of a national population of nine million. ${ }^{24}$

In addition, elected presidents of countries engaged in guerrilla warfare made ample use of paramilitary formations. In the late 1980s and the 1990s, during the counterinsurgency operations of the Fujimori government against the Maoist guerrilla group, Shining Path, the Peruvian Army eventually armed around 400000 indigenous paramilitary troops (ronderos in Peruvian Spanish), operating under authority of the local commanding officers. Their presence was the decisive factor with respect to the victory over this guerrilla group. ${ }^{25}$

Over many years, the Colombian Army maintained close ties with private armies, regional paramilitary forces that were finally unified into the umbrella organisation Autodefensas Unidas de Colombia (AUC). The most recent report of the Colombian Centro de la Memoria Histórica attributes $70 \%$ of the victims of massacres to the campaigns of the army and the paramilitary forces. ${ }^{26}$ 
During the Cold War, the military right was supported by the United States. The United States had already established a tradition of political policing by military intervention in the Americas. According to the database of Becker, between 1890 and 2009, the Americans intervened 62 times with regular troops, Special Forces, covert action operators and paramilitary forces. ${ }^{27}$ There was at least a state of complicity Operation Condor, an intelligence, death squad and dirty warfare cooperation structure between the intelligence services of Argentina, Bolivia, Brazil, Chile, Paraguay and Uruguay. ${ }^{28}$ Less documented is the role of Argentina in intelligence and dirty warfare support in Central America, before the United State took over. ${ }^{29}$

Coups and coup efforts of militaries of the right did not completely cease in the twenty-first century. In 2002, a coup against elected leftist President Chávez of Venezuela eventually failed after several days. In 2004, after a period of conflict between armed groups and the Haitian security forces, leftist elected President Aristide was ousted by US forces and set on a plane to the Central African Republic. In 2009, Honduran military forces captured leftist elected President Zelaya, and flew him to Costa Rica. In 2010, police and military officers tried to remove leftist elected Ecuadorean President Correa. He was liberated by loyal military.

Maybe the Honduran coup was the most explicit and violent removal of an elected president. Zelaya, a rich landowner, evolved during his government term to a leftist 'spokesman of the urban and rural poor' who flirted with the idea of an alliance with Cuban and Venezuelan politics to become a member of the string of other ALBA countries of Bolivia, Ecuador, Nicaragua and several smaller Caribbean island states. ${ }^{30}$ His adversaries discovered 'communism' within the presidential palace. A $60 \%$ increase in the national minimum salary decreed by the President was the limit. The cardinal and retired army generals were invited to comment on radio and TV on the dangers of communism. Right-wing opponents and the military leadership started negotiations about the convenience of a corrective coup. The military staff asked a donation of US\$ 10 million; the Honduran elite could however only amass US\$ 5 million in cash on short notice and the generals happily agreed. ${ }^{31}$ The coup was, in strictly military terms, a success. However, politically it resulted in disaster. All member states of the Organization of American States (OAS) reacted with dismay. The appointed interim government became a regional pariah and had to organise new elections.

\section{Military of the left}

Military men are not inevitably inclined to the political right. Throughout the entire twentieth century, there were revolutionary lieutenants and captains. In the 1920 s, rebellions erupted by young officers who in later years were characterised as the 'Military Youth' in Brazil, Chile and Ecuador. ${ }^{32}$ Also in later decades, Military Youth in Central America participated in rebellions with reformist agendas. ${ }^{33}$ In 1960 , young lieutenants in Guatemala with a nationalist and anti-imperialist agenda overthrew a military dictatorship and, after its failure, organised the first guerrilla groups in that country. In 1982 and 1983, young officers were instrumental in the 
overthrow of the two merciless dictators, Generals Lucas García and Ríos Montt. In 1972 and 1979, they were the actors behind the two last military coups in El Salvador before the civil war. It was a desperate effort to prevent large-scale guerrilla warfare.

More renowned were the governments of nationalist-leftist military leaders who used the armed forces to implement anti-oligarchic and anti-imperialist nationalisations and pro-poor social reforms after World War II. Many of them and their younger military ministers were of lower middle-class backgrounds or the precarious urban working class. ${ }^{34}$ They were elected or staged a coup and sought legitimisation by elections and/or by mass organisations. Colonel Arbenz (1950-1954) in Guatemala was the first one. He was elected president, maintaining his army rank, and initiated an Agrarian Reform while nationalising American property. His political successors, Generals Velasco Alvarado in Peru and Torrijos in Panama, headed institutional coups in the same year, 1968 .

Like the Velasco government in Peru, Panamanian army chief Torrijos announced a social reform programme for the benefit of the poor. ${ }^{35}$ Both were passionate nationalists with sympathy for the underprivileged. Both defined themselves as military reformers with a special mission to break the power of the economic and political oligarchy, to restore national control over the economy, and to carry out social reforms, implemented by the armed forces. Here is a quote from a discourse by Torrijos (that could have been uttered by either Velasco or three decades later by Chávez):

I am a soldier of Latin America who lives his daily life in the barracks since I was seventeen years old. That gives me the right, and knowledge, to treat a delicate, complex and sensitive subject [...]. Since 1959 , the year in which, utterly remarkably in our century, a guerrilla triumphs over a regular army in Cuba, at the peak of the period of McCarthyism, military schools began to analyse a problem that had not been recognised previously. What had happened in Cuba? And why? [...]: social terror, terrorism, 'exotic theories'. No, no, the real breeding ground for these so-called exotic theories is [poverty and] misery. The real cause is the lack of schools, the lack of provision of potable water, the lack of a national development programme [...]. Many common soldiers, sergeants and lieutenants, men who live in the same [circumstances of] misery in which ordinary people live, realise quickly that their rifles should be targeted at those who enslave $[\ldots] \cdot{ }^{36}$

Military reformism was not restricted to Panama and Peru. Other army chiefs followed suit and adopted similar, albeit more modest, programmes: in 1971 in Bolivia (Generals Obando [1969-1970] and Torres [1970-1971]) and in Ecuador (General Rodríguez Lara [1972]). In retirement, several of the reformist military founded an NGO (non-governmental organisation) for progressive former officers. ${ }^{37}$ 
At present (March 2019), we may be witnessing the emergence of a new variety of political armies in a new ideological dress, that of nationalist and anti-imperialist 'socialism-of the twenty-first-century'. In 2010, for instance, Bolivia's armed forces declared themselves a "socialist, anti-imperialist and anti-capitalist institution", in full support of President Morales' Plurinational State of Bolivia and the political ideology of the ruling MAS (Movement for Socialism) government. ${ }^{38}$ As in Bolivia and Peru, Venezuelan army officers are recruited from lower middle-class or labourclass families. Lieutenant Colonel Chávez, son of schoolteachers and educated by his grandmother, a life-long devotee of Bolivar and admirer of Velasco and Torrijos, staged a coup in 1992 . The coup failed..$^{39}$ When he was released from jail, he campaigned for presidential election in slums and rural villages. Like Velasco and Torrijos, Chávez was embedded in the military revolutionary mystique that supposes the indivisible unity between people and the Army. In his own words:

We can say that it is like the formula of water: $\mathrm{H}_{2} \mathrm{O}$. If we say that the People are the oxygen, the Armed Force is the hydrogen. Water doesn't exist without hydrogen. ${ }^{40}$

During the fifteen years of Chávez's presidency (1999-2013), his political trajectory demonstrated a deepening radicalism. ${ }^{41}$ A new constitution in 1999 established the Bolivarian Republic of Venezuela. He survived a (failed) coup in 2002 and a (failed) general strike organised by heterogeneous alliances of opposing military and political leaders. After purging the armed institutions, he eventually founded his own political party, a mixture of leftist political parties and social movements. ${ }^{42}$ His political management reflects a mixture of mass movements and use of the armed forces in civilian administration. In the mid-2000s, Chávez started expanding his reach, emphasising his 'socialism of the twenty-first century': a large series of domestic social and economic 'missions', headed by trusted military and loyal civilians. The Venezuelan armed force, now the 'National Bolivarian Armed Force', gradually became the executive instrument of the president. ${ }^{43}$ Between 2008 and 2015, the armed force's budget grew from $1,06 \%$ to $4,61 \%$ of the gross domestic product (GDP). Military personnel increased from 117400 in 2010 to 197744 in 2014 (from 40 to 63 per 10000 citizens). In 2015, the number of (auxiliary) people's militias stood at 365046 organised in 'integral defence areas' and 'military strategic defence regions' under military command. ${ }^{44}$

The social and political divide in Venezuela, already visible during Chávez's last years, became catastrophic under his successor Maduro's presidency (2013-present). After elections in January 2016, the opposition dominated parliament, but in May 2016, the government declared an emergency situation and organised elections for a Constituent Assemblée that de facto took over all parliamentary functions. Since then, the president rules by decree. Civilian ministries and management functions were increasingly transferred to the military. ${ }^{45}$ Military officers in active service or in retirement occupied key cabinet positions. Important sectors and strategic public instruments, such as tax collection, budgeting, public contracts and tendering, purchases and acquisitions of the public sector, public imports, control over the public banks and the superintendence of banks are all managed by military officers as well. ${ }^{46}$ 
Already under Chávez, the National Bolivarian Armed Forces were a powerful instrument, acting as both the right arm (defence and internal security) end the left arm (in charge of ministries, the ' missions' and economic management) of the president. ${ }^{47}$ The military also entered the realm of essentially civilian administration. Chávez's successor, civilian President Maduro, extended this system of selecting only fierce Chavista military loyalists. General Vladimir Padrino, commander-in-chief in 2013, was made Minister of Defence in 2014 and remain in charge until the present. Confronted with political mayhem and economic calamity, Maduro systematically transferred executive power to the military echelons. Currently, General Padrino oversees national defence, manages the national economy, at the same time monitoring all other social missions and is the de facto cabinet prime minister. The Armed Forces control $51 \%$ of the entire national budget. ${ }^{48}$ They also are in charge of the most vital cabinet positions: Defence, Interior, Justice, Alimentation, Housing, Public Works, Transport, and Electricity. The situation became even more complicated when in January 2019, the new president of the (original) parliament, Juan Gaidó, declared himself interim president. At present, Venezuela has two parliaments and two presidents. However, the Military High Command staunchly supports President Maduro (March 2019). The regime's future is strongly dependent on the loyalty of his military supporters.

\section{Democratic transition and nostalgia for military leadership}

The implosion of the Soviet Union, the transition of China as an emerging state capitalist power, and, of course, the wave of democratic transitions in the region ceased to sustain the national security doctrines of the Cold War era. With the exception of Colombia (where one guerrilla movement is still fighting) there are no armed insurgency movements with a politico-military agenda left. At present, Latin America and the Caribbean are ruled by elected governments. However, except for Argentina, all democratic transitions in Latin America were accompanied by explicit amnesties or pardon legislation. This created - and still causes - an impunity problem with respect to human rights violations committed by the security forces during the dictatorships. Special legislation and the easy delegation of judicial processes to the military justice system favour the practice of relative immunity in Brazil, Colombia, the northern triangle of Central America, Peru and other countries.

With the return to democracy in Latin America, a kind of civil-military accommodation process took place. Political militarism was abandoned, but the phenomenon of military politicians did not disappear; in some countries it was only modernised. In general, the Latin American and Caribbean electorates maintain a weak spot concerning soldiers in politics and former military strongmen of the left and the right. I already mentioned the case of President Chávez in Venezuela between 1999 and 2013. The region even witnessed the election of the presidency by former conservative dictators as doctored democrats: In Bolivia, former dictator General Banzer won the presidential elections in 1998. In Guatemala, Banzer's colleague, former dictator General Rios Montt, was invested with the Presidency of the national Congress in 1999. His party had won the elections, and President Portillo figured 
as his figurehead while Rios Montt coordinated the cabinet. In 2010 and 2015, two times putchist and ex-dictator Bouterse, condemned drug dealer (in The Netherlands) and accused of torture and murder by a military tribunal (in Suriname), won the presidential elections of Surinam. Again in Guatemala, former General Pérez Molina was elected president in 2011. Campaigning under the banner of law and order, and heavily supported by the national billionaire elite, he, his vice-president and his key cabinet members went to jail for corruption in the last year of his term.

Notwithstanding previous experiences under military dictatorships, the public's confidence in the armed forces remained high. In most public opinion polls in the region (a consistent phenomenon in the yearly reports of the Latinobarómetro for twenty years), the confidence in institutions is, in descending order: ${ }^{49}$

- $\quad$ the churches $-66 \%$;

- the armed forces $-50 \%$;

- $\quad$ the police $-38 \%$;

- the electoral institutions $-32 \%$;

- $\quad$ the government $-26 \%$;

- $\quad$ the judiciary $-28 \%$;

- $\quad$ the parliament $-25 \%$; and

- $\quad$ the political parties $-17 \%$.

At least in part, the continuous prestige of the military is explained by the development tasks that the military traditionally performs in garrisons and deployments in remote areas: infrastructure, medical service, and sometimes transport in emergency situations.

\section{Conclusions: New military security missions and 'unconventional' counterinsurgency}

In Bolivia, Brazil, Colombia, El Salvador, Honduras, Guatemala, Nicaragua, Mexico, Paraguay, Peru, Uruguay and Venezuela, civilian governments formally established internal security missions to the armed assigned by presidential decrees and/or parliamentary legislation to the Armed Forces to act in new missions of internal security and development. The development missions are an extension of the already mentioned civilian assistance missions in remote or underdeveloped and faraway regions. The new missions refer to environmental issues, protection of the biodiversity, role expanding as key actors in 'civil defence' and assistance in natural disasters. ${ }^{50}$ Emphasis is also put on participation in peace missions. During the last decades, military contingents of many Latin American countries participated in foreign peace missions, operating under a United Nations mandate. These missions are continued to the present. ${ }^{51}$ From 2004 on, Brazil and Chile headed the UN Stabilization Mission in Haiti (MINUSTAH). ${ }^{52}$ Argentina, Brazil, Chile, and Peru created special peacekeeping schools. ${ }^{53}$ 
Other recent missions are not related to external defence or internal development. After the democratisation of the entire region and the end of civil wars in Central America and the Andean countries (Colombia and Peru), new waves of violence and new armed actors appeared in the form of local mini-wars in favelas (low- and middle-income, and unregulated neighbourhoods in Brazil), popular neighbourhoods and rural corridors of drug trafficking. In many countries, civilian governments and parliaments provide binding legislation to the armed forces to act in new missions of internal security, to 'assist the police' or even to assume command of the operations against cartels and crime syndicates, youth gangs, and urban vigilantes. However, rough military and police detachments, private security companies and violent law enforcement agencies are also the actors or partners in the so-called 'new violence' in Latin America. ${ }^{54}$

Between 2000 and 2017, more than 2,5 million Latin Americans have been killed by violence, generally by intentional homicide. In 2012, Latin America's citizens represented only $8 \%$ of the world's population; however, they produced $33 \%$ of the world's homicides in 2012, and this trend is not declining. ${ }^{55}$ With the exception of drugrelated violence in Colombia, Central America and Mexico, Latin American violence is predominantly urban. According to the Mexican NGO Seguridad, Justicia y Paz, from the 50 most lethal cities of 300000 inhabitants or more in the world in 2016, 42 are in Latin America (and one, Kingston, in the English-speaking Caribbean). ${ }^{56}$ Of these Latin American cities, 19 are in Brazil, 8 in Mexico, 7 in Venezuela and 4 in Colombia. Caracas is the most violent city with 130 assassinations per 100000 inhabitants. Most of the victims live in urban peripheries, are male, young, non-white, and killed by firearms. This 'new warfare' was not limited to urban territories, but quickly expanded to rural areas in Colombia, Central America and Mexico.

The presence of drugs, the cultivation, transformation, commerce and smuggling of cocainepoppy and marihuana, produced an expansion of violence by non-state and state actors, and in some countries caused more victims than in the decades of civil wars. The focus on the 'war on drugs' implies a permanent intertwining of US anti-drug agencies and national police and military forces. This imposes a militaristic approach to the drug problem. After 9/11, this has been strengthened by the fusion of the 'war on dugs' and 'war on terror' discourses that engage with the connection between drug trafficking and armed actors that challenge the violence monopoly of states in the region. However, as we will illustrate below with a few examples, this militarisation of internal law enforcement has not (yet) led to the impending remilitarisation of politics, but has rather accentuated the intrinsically violent nature of democracy in Latin America. ${ }^{57}$

Reluctantly or not, given the absence of external warfare, Latin American armed forces have assumed a multiplicity of internal security missions:

- the military as provider of internal security;

- $\quad$ the military as parallel police force; 
- the military as principal actor of internal warfare, be it against 'terrorists' or 'organised crime';

- $\quad$ the military as pacifier in slum wars;

- the military as the ultimate resort against gang lords in the drugs corridors.

Eventually, one can observe a reciprocal process: the militarisation of the police with 'Special Police Forces' trained in urban warfare and armed with heavy weaponry. Even the language of these 'civilian missions' is embedded in soldiers' semantic: the war against crime, the war against terrorists, and the war against drugs. Some of the new missions are far-going role extensions. However, all new missions are being requested or at least permitted by democratically elected governments and are based on legal charters. This is a fundamental difference in comparison with the decades of military dictatorship where hidden and veiled intelligence and security operations were executed by paramilitary forces and death squads, without constitutional or legitimate mandates.

What is, however, beyond legitimacy is the phenomenon of coups by invitation or self-coups by elected presidents. In the recent past, the self-coup by elected President Fujimori in Peru (1991) was extremely successful. Afterwards, he governed by decree and was re-elected in 1995 with an overwhelming majority of 64\%. His colleague, elected President Serrano in Guatemala, followed his example, but his self-coup failed. The military was divided over its consequences and along with mass demonstrations against the take-over decided to transfer power to the Congress. The negotiated coup in 2019 against Honduran President Zelaya technically succeeded but the new government was tainted, and the country was transformed into an international pariah until externally controlled elections had been organised.

Venezuela under Maduro is another case of contention. After legislative elections in December 2015, the president was confronted by a new parliament (Assemblée) in which the opposition had won a two-thirds majority. The president organised elections for a new Constitutional Congress, the opposition boycotted elections, and Maduro won a devoted membership. He transferred all legislative functions to this new body, and in 2017, organised contested elections for municipal mayors and state governors. The incumbent president was re-elected for a second six-year term. In his cabinet, all key functions were consigned to loyal generals. All strategic public institutions tax collection, budgeting, public contracts and tendering, purchases and acquisitions within the public sector, public imports, control over the public banks and the superintendence of banks - were managed by junior generals and colonels. In fact, the armed forces were the regime's right arm (executive functions) and the left (repression by the military National Guard)

A completely new situation has arisen in Brazil. During the impeachment procedure against President Rousseff, politicians of the right and the left invited the military high command to pronounce political statements. Initially, the answer was negative, but in the subsequent process against former president Lula, the general staff voiced their 
preferences. Prior to and during the presidential elections in 2018, far-right congressman, Bolsonaro's, a former army captain who repeatedly expressed his admiration for Brazil's military dictatorship, announced his plan to appoint the military in key posts and to clean the country while dealing with his adversaries. At present (March 2019), it is too early to predict the political course of the country. Bolsonaro's own party has only a small number of seats and he will have to accommodate politically close and distant allies to rule with a majority in Congress. His veiled bidding to the armed forces to co-govern, however, opens the way for the military in politics. The last word about the future of Latin American political Armies has not been spoken yet.

\section{Endnotes}

${ }^{1}$ In a previous version, this article was presented as a keynote address at the Conference of the International Sociological Association, Research Committee on Armed Forces and Conflict Resolution (RC01), Fundação Getulio Vargas, Rio de Janeiro, 24-27 September 2016. In this contribution, I draw on D Kruijt. The political influence of the Latin American military. Working paper no. 30. Amsterdam: Centre for Latin American Research and Documentation. October 2017. < http://www.cedla.uva.nl/50 publications/ pdf/cuadernos/30-Cuadernos_Working_Paper-Dirk_Kruijt.pdf $>$ Accessed on 18 November 2018. I thank Kees Koonings for his critical review of former drafts.

${ }^{2}$ See M Kaldor. Beyond Militarism, Arms Races, and Arms Control. Essay for the Nobel Prize Centennial Symposium. London: Social Science Research Council, 2001.

${ }^{3}$ See K. Koonings \& D Kruijt. "Military politics and the mission of nation building". In K Koonings \& D Kruijt (eds), Political armies: The military and nation building in the age of democracy. London: Zed Books, 202, 9-34.

${ }^{4}$ See ED Arias \& DM Goldstein (eds). Violent democracies in Latin America. Durham: Duke University Press, 2010.

${ }^{5}$ See B.Loveman. The Constitution of Tyranny. Regimes of Exception in Spanish America. Pittsburgh: University of Pittsburgh Press, 1993.

${ }^{6}$ Even masculine versus feminine. Guatemalan General-President Romeo Lucas García (1978-1982) considered democracy as 'feminine'. He was toppled by young officers who staged a coup and handed over power to General Rios Montt.

${ }^{7}$ See K. Koonings \& D Kruijt, op. cit.

${ }^{8}$ See B Loveman. The constitution of tyranny: Regimes of exception in Spanish America. Pittsburgh, PA: Pittsburgh University Press, 1993; for Brazil, see FD McCann. Soldiers of the Pátria: A history of the Brazilian Army, 18891937. Stanford: Stanford University Press, 2004. For Central America, see B Arévalo de León. Del Estado Violento al Ejército Político: Formación estatal y función militar en Guatemala (1524-1963). Guatemala: F \& G Editores, 2018. 
${ }^{9}$ See Loveman, Brian. 'Military Government in Latin America, 1959-1990', in Oxford Bibliographies, 28 October $2011<$ http://www.oxfordbibliographies. com/view/document/obo-9780199766581/obo-9780199766581-0015. xml.>Accessed on 22 August 2017

${ }^{10}$ A Rouquié. The military and the state in Latin America. Berkeley, CA: University of California Press, 1987, 95.

${ }^{11}$ See Silva, G. do Couto e. Planejamento estratégico. Rio de Janeiro: Livraria José Olympio, 1981. [initial surname]

${ }^{12}$ See A Pinochet Ugarte. Geopolitica ( $2^{\text {nd }}$ ed.). Santiago de Chile: Editorial Andres Bello, 1974.

${ }^{13}$ See E Mercado Jarrín. Seguridad, politica, estrategia. Lima: Estado Mayor General del Ejército, Departamento de Relaciones del Ejército, 1975.

${ }^{14}$ See HA Gramajo Morales. Tesis de la Estabilidad Nacional. Guatemala: Ministerio de la Defensa, Editorial del Ejercito, 1989.

${ }^{15}$ For Brazil, see RA Hayes. The armed nation: The Brazilian corporate mystique.

Tempe: Arizona State University, 1989 and T Skidmore. The politics of military rule in Brazil, 1964-1985. New York, NY: Oxford University Press, 1988. For Peru, see V Villanueva. El CAEM y la revolución de la Fuerza Armada. Lima: Instituto de Estudios Peruanos and Campodónico Editores, 1972 and D Kruijt. La revolución por decreto. El Perú durante el gobierno militar. Serie Democracia y Fuerza Armada 9. Lima: Instituto de Defensa Legal, 2008.

${ }^{16}$ See AC Stepan. The military in politics: Changing patterns in Brazil. Princeton, NJ: Princeton University Press, 1971, 171 ff.

${ }^{17}$ Three of the founding board members of the Fundación DIG were former president Arévalo (1944-1950), who initiated the period of the "Guatemalan Spring" and was succeeded by Colonel Arbenz; President-General Arana, who crushed the guerrilla of the 1960s, and afterwards was appointed ambassador to Nicaragua's dictator Somoza and eventually ruled the country as elected president between 1970 and 1974; and General Gramajo, Minister of Defence (1987-1990).

${ }^{18}$ For a recent characterisation of this type of coups, see F Lehoucq \& A Pérez-Liñán. "Breaking out of the coup trap: Political competition and military coups in Latin America”. Comparative Political Studies 47/8. 2014. 1105-1129.

${ }^{19}$ See C Castro, MC D'Araujo \& GA Dillon Soares (eds). Visões do golpe. A memória militar sobre 1964. Rio de Janeiro: Relume-Dumará, 1994 and C Castro, MC D'Araujo \& GA Dillon Soares (eds). Os anos de chumbo. A memória militar sobre a repressão. Rio de Janeiro: Relume-Dumará, 1994.

${ }^{20}$ See R Dreifuss. 1964. A conquista do estado. Ação política, poder e golpe de classe. Petrópolis: Vozes, 1981.

${ }^{21}$ And the Carabineros in the case of Chile. 
${ }^{22}$ According to the Comisión pare el Esclarecimiento Histórico (CEH), the UN Truth Commission in Guatemala; see CEH. Guatemala. Memoria del silencio. Volume 1. Guatemala: United Nations Office for Project Services, 1999.

${ }^{23}$ See here M Esparza, HR Ruttenbach \& D Feierstein (eds). State violence and genocide in Latin America: The Cold War years. Abingdon: Routledge, 2010 and J Mazzei. Death squads or self-defence forces? How paramilitary groups emerge and challenge democracy in Latin America. Chapel Hill, NC: The University of North Carolina Press, 2009.

${ }^{24}$ According to the author's interview with former peace negotiator Héctor RosadaGranados (Guatemala City, 14 April 2010); see also D Kruijt. Guerrillas: War and peace in Central America. London: Zed Books, 2008, 31-32) and ME Vela Castañeda. "Perpetradores de genocidio: Aproximaciones históricas y sociológicas desde el caso Guatemala". Nueva Sociedad 246. July-August 2013. 167-169.

${ }^{25}$ See M Fumerton. From victims to heroes: Peasant counter-rebellion and civil war in Ayacucho, Peru, 1980-2000. Thela Latin America Series. Amsterdam: Rozenberg, 2002.

${ }^{26}$ National Centre for Historical Memory. Basta Ya! Colombia: Memories of war and dignity. Bogota, 2016, $43 \mathrm{ff}$.

${ }^{27}$ See M Becker History of U.S. Interventions in Latin America, $<$ https://www.yachana.org/teaching/resources/interventions.html > Accesed on 16 August 2017

${ }^{28}$ See JP McSherry. Predatory states: Operation Condor and covert war in Latin America. Lanham: Rowman \& Littlefield, 2005. The Clinton administration declassified numerous state department documents.

${ }^{29}$ However, see AC Armony. Argentina, the United States, and the anti-communist crusade in Central America 1977-1984. Athens, OH: Center for International Studies, Ohio University, 1997 and J Rostica. "La Confederación Anticomunista Latinoamericana. Las conexiones civiles y militares entre Guatemala y Argentina (1972-1980)". Revista Desafios 30/1. 2018. 309-347.

${ }^{30}$ ALBA is the Alianza Bolivariana para los Pueblos de Nuestra América (Bolivarian Alliance for the People of Our America).

${ }^{31}$ Author's interview with Víctor Meza, at that time minister of the interior of President Zelaya (Tegucigalpa, 26 and 27 October 2010). For a more detailed analysis, see L Salomón. "Political system, armed forces and interruption of constitutional order". In Red de Seguridad y Defensa de América Latina. A comparative atlas of defence in Latin America and the Caribbean. Buenos Aires, 2010, 240-241. 
${ }^{32}$ In Copacabana, Rio de Janeiro, a movement of tenentes (lieutenants) revolted asking for electoral and political reforms in 1922. In 1924, tenentes in São Paolo and Rio Grande do Sul took up the cause of opposition movements; their rebellion lasted several years (McCann op. cit., p. 259 ff.). In 1924, in Chile, a military committee of young officers protested low salaries and revolted against Congress requiring immediate social legislation. A military reformist junta was installed, and a short-lived socialist republic was even proclaimed. In 1925, in Ecuador, the League of Young Officers rebelled against the repressive government and accelerated social legislation and 'protection for the proletariat'; a second coup in 1931 ended this reformist experiment; see PE Ospina Peralta. "La alineación inestable. Origen y consolidación de un Estado transformista: Ecuador, 1920-1960". PhD thesis. University of Amsterdam, 2016, $142 \mathrm{ff}$.

${ }^{33}$ A Martín Álvarez. "The long wave: The revolutionary left in Guatemala, Nicaragua, and El Salvador". In A Martin Álvarez \& E Rey Tristán (eds), Revolutionary violence and the new left: Transnational perspectives. Abingdon: Routledge, 2017, 223-245.

${ }^{34}$ Rouquié presents an overview of the background of the officers of significant Latin American armies in the 1980s and concludes that, maybe except for the Argentinean army, officers' recruitment slowly had been focused on the lower middle classes (Rouquié op. cit., pp. 84-93).

${ }^{35}$ For a very detailed analysis of Velasco's legacy, see C Aguirre \& P Drinot (eds). The peculiar revolution: Rethinking the Peruvian experiment under military rule. Austin, TX: The University of Texas Press, 2017.

${ }^{36}$ M Zárate \& D Vargas (eds). General Omar Torrijos de Panamá y de la Patria Grande. Caracas: Editorial Trincheras, 2011, 255-261.

${ }^{37}$ The Organización de Militares para la Democracia, la Integración de América Latina y el Caribe (ORMIDELAC) (the Organisation of Military Officers in Favour of Democracy and Integration of Latin America and the Caribbean).

${ }^{38}$ See El Pais, 16 November 2010. The journal quotes Bolivian army chief General Cueto, whose public declaration at the Colegio Militar en La Paz was shared by a visibly emotional President Morales. MAS is Movimiento al Socialismo (Movement towards Socialism), an alliance of several parties and social movements.

${ }^{39}$ Here I draw on chapters 6 and 7 of D Kruijt. Cuba and revolutionary Latin America: An oral history. London, Zed Books, 2017.

${ }^{40}$ L Bilbao. Chávez y la Revolución Bolivariana. Conversaciones con Luis Bilbao. Santiago de Chile: Capital Intelectual S.A. and LOM Editores, 2002.

${ }^{41}$ Here I draw on R Gott. Hugo Chávez and the Bolivarian Revolution. London: Verso, 2005 and S Ellner. El fenómeno Chávez, sus orígenes y su impacto (hasta 2013) ( $2^{\text {nd }}$ ed). Caracas: Fundación Centro de Estudios Latinoamericanos Rómulo Gallegos and Centro Nacional de Historia, 2013. 
${ }^{42}$ The Partido Socialista Unido de Venezuela (PSUV, the United Socialist Party of Venezuela).

${ }^{43}$ About the new emerging military ideology, see M Anselmi. Chávez's children: Ideology, education and society. Lanham: Lexington Books, 2013.

${ }^{44}$ According to Red de Defensa y Seguridad de América Latina. Atlas comparativo de la defensa en América Latina y Caribe. Buenos Aires, 2016, 210-215, these ZODI (Zonas de Defensa Integral) and REDI (Regiones Estratégicas de Defensa Militar) were created by Chávez.

${ }^{45}$ For details, see C Tablante \& M Tarre. El gran saqueo: Quiénes y cómo se robaron el dinero de los venezolanos. Caracas: La Hoja del Norte, 2015, 260-266.

${ }^{46}$ For a detailed analysis, see F Ramos Pismataro \& RF Rodríguez. 'Venezuela y la revolución perpetua, Razón Pública. 25 July 2017. <https://www. razonpublica.com/index.php/internacional-temas-32/10423-venezuela-yla-revoluci\%C3\%B3n-perpetua.html> Accessed on 26 July 2017.

${ }^{47}$ The intelligence services (Servicio Bolivariano de Inteligencia Nacional, SEBIN).

${ }^{48}$ Transparencia Venezuela. Empresas propiedad del estado en Venezuela. Un modelo de control del Estado. September 2017, 7. <https://transparencia.org.ve/ wp-content/uploads/2017/09/Empresas-propiedad-del-Edo.-2017-TV-sinlinea-de-corte.pdf> Accessed on 11 April 2018.

${ }^{49}$ The order is calculated on the basis of the average scores between 1995 and 2016; the scores of 2016 are mentioned in the text (Latinobarómetro. Informe 2016. Buenos Aires: Corporación Latinobarómetro. 2016, $32-33,<$ http://www.latinobarometro.org/latNews ShowMore. jsp? evYEAR=2016\&evMONTH=-1>Accessed on 6 May 2017.

${ }^{50}$ In the majority of countries in the region, these missions have a constitutional (in Bolivia, Ecuador, El Salvador, Honduras, Peru and Suriname) or at least a legal base (in Chile, Colombia, Cuba, the Dominican Republic, Guyana, Nicaragua, Mexico, Paraguay and Venezuela). Protection of the environment and assistance in the case of national disasters (earthquakes, hurricanes, flood disasters and tsunamis) are considered a regular supporting role of the Latin American and Caribbean armed forces (D Kruijt \& K Koonings. "From political armies to the 'war against crime': The transformation of militarism in Latin America". In A Stavrianakis \& J Selby (eds), Militarism and international relations: Political economy, security, theory. Series Cass Military Studies. Abingdon: Routledge, 2013, 99.

${ }^{51}$ Here I draw on WA Sánchez Nieto. "Brazil's grand design for combining global South solidarity and national interests: A discussion of peacekeeping operations in Haiti and Timor". Globalizations 9/1. 2012. 161-178. doi: 10.1080/14747731.2012.627719. Probably the first Latin American peace mission was the Battalion Peru, an army unit dispatched by Peruvian President-General Velasco as peacekeepers after the Yom Kippur War between Israel and Egypt. 
${ }^{52}$ Brazil initially deployed 1300 military, other Latin American countries (Argentina, Bolivia, Chile, Colombia, Ecuador, Guatemala, Paraguay, Peru and Uruguay) sent smaller contingents; approximately 9000 Latin American soldiers participated.

${ }^{53}$ The Latin American Association of Training Centres for Peace (ALCOPAZ by its Portuguese and Spanish acronyms) is based in Rio de Janeiro.

${ }^{54}$ About this complex situation, see ED Arias \& DM Goldstein (eds, op. cit. , K Koonings \& D Kruijt (eds). Violence and resilience in Latin American cities. London: Zed Books, 2015 and R Muggah \& K Aguirre Tobín. "Citizen security in Latin America: Facts and figures". Strategic paper no. 33. Rio de Janeiro: Igarapé Institute, April 2018.

$<$ https://igarape.org.br/wp-content/uploads/2018/04/Citizen-Security-in-LatinAmerica-Facts-and-Figures.pdf $>$ Accessed on 25 April 2018.

${ }^{55}$ R Muggah \& K. Aguirre Tobón, 2018. Citizen security in Latin America: Facts and

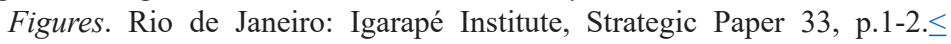
https://igarape.org.br/wp-content/uploads/2018/04/Citizen-Security-inLatin-America-Facts-and-Figures.pdf $>$ Accessed on 28 January 2019.

${ }^{56}$ Seguridad, Justicia y Paz, Metodología del ranking (2016) de las 50 ciudades más violentas del mundo, <https://www.seguridadjusticiaypaz.org.mx/ biblioteca/prensa/send/6-prensa/239-las-50-ciudades-mas-violentas-delmundo-2016-metodologia $>$ Accessed on 21 February 2018.

${ }^{57}$ see ED Arias \& DM Goldstein (eds), op. cit. 